\title{
IMPROVING THE INTERACTION OF STATE INSTITUTIONS FOR THE CONTROL OF DISPLACED GOODS ACROSS THE CUSTOMS BORDER OF UKRAINE USING THE "SINGLE WINDOW" MECHANISM
}

The creation and use of the principle and mechanism of a "single window" for international trade contributes to the optimization of control procedures in the framework of movement of goods units across the customs border of Ukraine and increasing the institutional capacity of state institutions. The implementation of the "single window" mechanism in customs, sanitary-epidemiological, veterinarysanitary, phytosanitary, environmental, radiological and other types of state control is complicated by the inconsistency of the regulatory framework on the functioning of the "single window" both in the customs sphere and in implementation of other types of state control; the imperfection of the organizational and technical support of the functioning of the "single window"; insufficient use of risk-based methods for the selective selection of control objects. The study found that, thanks to the introduced legislative changes, it was possible to get closer to the basic principles of organizing a "single window" for the implementation of: standardization in providing information and presenting documents required for all types of state control through a single information channel; the coordination of the actions of the control authorities in connection with the election of the chief authority in the system of control authorities (as a rule, this is a customs authority) of the body that coordinates their activities; one-time implementation of control procedures with the inspection of goods.

The article focuses on the need as soon as possible to conduct information and technological coordination of the interaction of state institutions for the control of displaced goods across the customs border of Ukraine to prepare a list of information presented by government authorities as well as the content and format of these data; approving a set of harmonized information for presentation using a single state information web portal "Single Window for International Trade"; the exchange of experience with the Ministry of Environmental and Natural Resources of Ukraine, the State Environment Inspectorate and the organization of training seminars on the control by customs officers of specific foreign economic operations. It has been substantiated that the full functioning of the "single window" mechanism will contribute to the fulfillment of a number of international legal obligations of Ukraine within the framework of the WTO, will improve the conditions for conducting foreign economic activity in Ukraine.

Key words: state service, state institutions, control authorities, customs control, customs procedures, interaction of state institutions, the single window mechanism, reforming of state institutions.

JEL Classification: H11, D73.

\section{Olha BORYSENKO,}

University of Customs and Finance, Ukraine

acu_borysenko@ukr.net

\section{Olha BORKUT,}

"Odesa-Central» Customs Office of Odessa Customs,

State Fiscal Service of Ukraine,

Ukraine

borkutolga@ukr.net

\section{Introduction}

The objective need to integrate Ukraine into modern institutional structures of the global economy, world trade, which covers not only trade in goods, but also cross-border flows of services and intellectual property real opportunity to use the benefits of participation in the WTO from the point of view of national interests, strengthening national competitiveness, returning lost and gaining new positions in world markets, 
necessitated the need to enhance the regulatory role of the state in the development of full-time transformation of the economy, set new requirements to the state administration of foreign economic processes. Large-scale modernization of the national economy is inextricably linked to the reform of the implementation of state control functions at the border of Ukraine, requires a significant deepening of the interaction of various structures involved in regulating foreign economic operations to streamline standards, rules and procedures when moving goods across the customs border of our country.

The lack of coherent and systematic activities of the state and its institutions during the implementation of modern reforms with the gradual evolutionary development of procedures and rules in the sphere of foreign economic activity has created a contradiction between new dynamic market relations oriented to the wide participation of actors in world processes and the current system of governance, which is constantly lagging from the turbulent flow of economic transformations and in fact slows them down. The solution of this contradiction requires the formation of a modern paradigm of public administration in the sphere of foreign economic activity based on the introduction of the "single window" principle in innovative technologies in public management.

The creation and use of the principle and mechanism of a "single window" for international trade is recognized as the best international practice, contributes to international trade, streamlining activities during control procedures within the movement of commodity units across the customs border and, at the same time, enhances the institutional capabilities of state institutions. The need to introduce a "single window" at the customs border is recognized by the World Customs Organization (WTO Framework Standards), the United Nations Economic Commission for Europe (Recommendations 33-35 of the Center for Trade Facilitation and Electronic Business UN / CEFACT), the EU-Ukraine Association Agreement (article 76 on the application of EU guidelines, such as Customs prototypes (Customs blueprints). The draft law No. 7010 "On Amendments to the Customs Code of Ukraine and some other laws of Ukraine on the introduction of a "single window" mechanism and optimizing the implementation of control procedures when goods move across the customs border of Ukraine, September 5, 2018 with amended by the President, as a whole, was adopted by the Verkhovna Rada can be considered as one of the ways to improve the "single window" mechanism.

\section{Literature Review}

Significant developments in the field of research of theoretical foundations and institutional factors for the formation of an effective system of state regulation in the foreign economic policy, the importance of control authorities in the institutional mechanism for the formation and implementation of customs policy was carried out by such scientists as IG Berezhnyuk, L. Ivashova, I. M.Kveliashvili, V.P.Naumenko, P.V.Pashko, P.Pisnoy, D.V. Priymachenko, G.Yu.Razumei, V.V.Chentsov and many others. Considering the special importance of the effective development of the foreign economic, the organization of control and regulation in this direction and the maintenance of the economic security of the state with the aim of general economic development, many well-known modern scientists pay attention to the study of these issues. Moreover, all theoretical developments in this area are somehow connected with the issues of state regulation of foreign economic activity as the basis of state policy in the sphere of foreign economic relations and the role of state and non-state institutions in its provision. It should be noted that the recent transformations of the current national legislation, changing the 
role of state institutions in building a democratic, social and legal state identified a number of problems whose urgent solution is essential.

The introduction of the "single window" technology in the sphere of state regulation is considered in the works of K. Apanasenko, A. Brachuk, N. Bulychev, B. Kormich, Yu. Kuneva, A. Makarenko, V. Naumenko, Yu. Pivovar, G. Pisarenko, V . Platonov, I. Sitko, V. Timoshchuk, I. Fedotova and others. It is advisable to study the process of reforming the activities of state institutions in the context of active reformatting the interaction of state authorities in the direction of optimizing control over displaced goods across the customs border of Ukraine.

It should be noted, paying tribute to the results of scientific research on this issue, that within the framework of the implementation of administrative reform aimed at improving the functioning of all public authorities, the issues of improving the interaction of state institutions for controlling displaced goods across the customs border of Ukraine with using the "single window" mechanism, did not receive information and analytical support and did not find the proper scientific basis of. In particular, there is some uncertainty in the positions of researchers on the distribution of the functions of officials of various state control services, the mechanism of practical coordination of state authorities exercising control functions, which necessitates additional consideration of this issue.

\section{Summary of the main provisions}

The government made an important step in the implementation of the "single window" in August 2016 with the entry into force of the Resolution of the Cabinet of Ministers of May 25, 2016 No. 364 "Some issues of the implementation of the" single window "principle in the implementation of customs, sanitary-epidemiological, veterinary-sanitary, phytosanitary, environmental, radiological and other types of state control", however, there are a number of problematic aspects arising in the operation and development of this mechanism.

Firstly, there is an inconsistency of the regulatory framework on the functioning of the "single window" both in the customs sphere and in the implementation of other types of state control. Thus, the practice of providing documentation immediately in paper and electronic forms remains common, and explains the existing legislative and regulatory requirements.

Secondly, there is the imperfection of organizational and technical support of the functioning of the "single window". According to the Analytical Report "Simplification of trade procedures in Ukraine: Estimates and Business Expectations - 2017" prepared by the Institute for Economic Research and Policy Consulting, time spent at customs has not changed for $52 \%$ of exporters and $54 \%$ of importers polled.

Thirdly, there are insufficient use of risk-oriented methods for selective selection of objects of control.

Thus, although according to the State Fiscal Service data, on average, $89 \%$ of cargoes are processed through the "single window" system, still today the main goal of the "single window" mechanism operation, which is to simplify trade and reduce business time, is still not achieved when passing the procedures of registration of commodity units from a single submission by the enterprise of a standardized data set, which will allow all control authorities to use them within the "single window" [9].

On October 4, 2018, the Law of Ukraine on the introduction of a "single window" mechanism and streamlining the implementation of control procedures for the movement of goods across the customs border of Ukraine came into force. This law also amended the package of 
35 laws identified as necessary to improve the business climate and economic growth in the country. It's the document, which, in essence, legalized the changes that have already been introduced by the government at the level of bylaws, contains a number of important innovations. In particular, the law for the first time proposed the definition of the term "single window mechanism", as a mechanism for interaction between declarants, their representatives and other interested persons and income authorities and fees, other state authorities, institutions and organizations authorized to perform certain control or authorization functions regarding goods, vehicles across the customs border of Ukraine, that will provide the interested person with the opportunity at one time to submit electronically to the single information web portal a set of harmonized information in order to comply with the requirements for the movement of goods and vehicles across the customs border of Ukraine, provided for by the Customs Code, other laws of Ukraine, international treaties of Ukraine, consent to be bound which provided by the Verkhovna Rada of Ukraine, other regulatory acts [12].

In the previous edition of the Customs Code of Ukraine there was only a mention of the "single window", without any terminology and detail. So, in the fourth part of Article 319 it is indicated that the control over the movement of certain types of goods across the customs border of Ukraine is carried out by other state authorities, carried out according to the "single window" principle, which corresponds to international practice and recommendations of international organizations in the application of a single information and telecommunication system with the income authorities and fees. However, this provision of the Customs Code of Ukraine is almost impossible to implement without amending other laws of Ukraine, which regulate the implementation of relevant types of control and the provision of relevant permits, because today these laws provide for the issuance of relevant documents only on paper. Thus, the changes proposed by the legislators allowed to get closer to the basic principles of the organization of a "single window", formulated by world practice, on the implementation of:

* standardization of information provision, namely: the documents necessary for carrying out all types of state control are submitted once through a single channel;

* coordination of actions of supervisory authorities in connection with the election of the main one in the system of supervisory authorities (usually a customs authority) of the authority that coordinates their activities. If for control requires the inspection of goods, the main authority coordinates other authorities to conduct such an inspection at the same time;

* one-time control procedures, which consists in the implementation, if necessary, sampling of goods and samples, such a selection with the inspection of goods $[1,8,13,14]$.

For interaction between the declarant and the customs authorities, the order has to be settled at the legislative level, which should ensure (fig. 1):

* exchange of documents and information regarding the movement of goods, vehicles through the customs border of Ukraine between interested parties;

* transfer by state authorities, institutions and organizations of the relevant permits documents or information about the introduction (exclusion) of goods into the relevant register in the income authorities and fees in electronic form using electronic digital signature (EDS) means;

* the use by income authorities and fees of information from relevant registers or documents;

* the provision by authorized authorities carrying out sanitary, phytosanitary inspections of goods and vehicles imported into the customs territory of Ukraine (also for the purpose of transit) of information on the results of such activities;

* multiple use of one-time entered information; 
* coordination by the income authorities and fees of control measures by the authorized authority implementing sanitary, phytosanitary measures in relation to goods, vehicles, etc. [5].

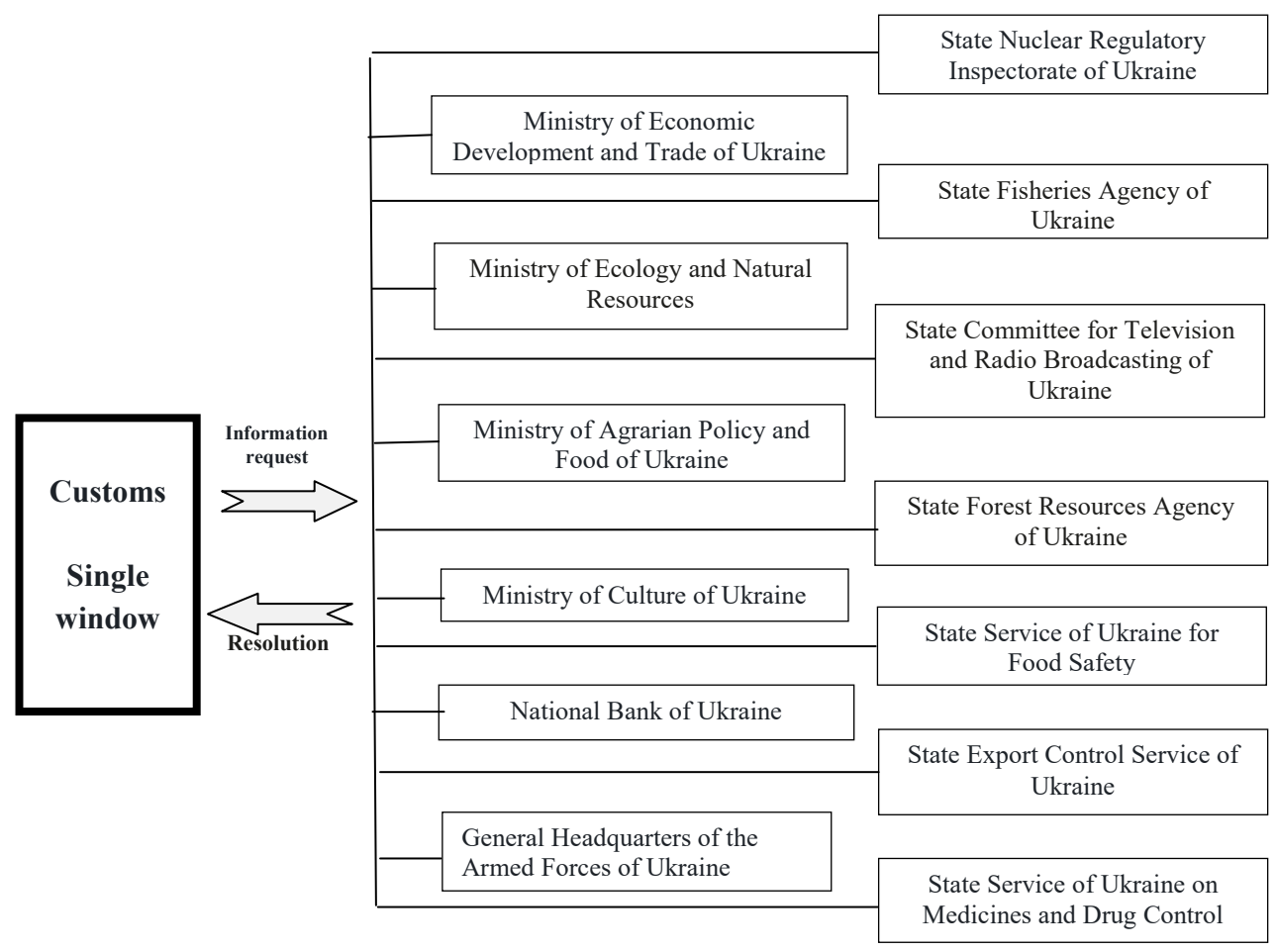

Fig. 1. Information interaction of state institutions in the framework of the use of the single state information web portal "Single Window for International Trade"

Thus, the number of necessary permits used in customs control and customs clearance of goods and the number of control authorities at the border are reduced due to the delegation of authority exercised with:

* the assignment of duties on the verification of permissive documents on customs officials, which today are carried out by officials of the State Environmental Inspectorate;

* the assignment of duties to officials of the State Border Service regarding the verification of the level of radioactive contamination of vehicles and cargo imported into the customs territory of Ukraine, today are carried out by officials of the State Environmental Inspectorate;

* the abolition of the sanitary-epidemiological control of commodity units moved across the customs border of Ukraine [12].

\section{Discussion}

According to the legislators, sanitary and epidemiological control of goods de facto boils down to obtaining a "conclusion", that is, a certificate, the basis for the publication of which is a statement that in no way indicates a real inspection and safety of a specific consignment of goods, this conclusion actions up to 5 years. With the adoption of the law, the conclusion was eliminated as a permissive document for import, as it was exclusively a bureaucratic obstacle to 
international trade. But, with the aim of improving the legislation on ensuring the sanitary and epidemiological welfare of the population and optimizing the procedure for conducting sanitary-epidemiological surveillance with relevant amendments to Article 16 of the Law of Ukraine "On ensuring the sanitary and epidemiological welfare of the population", as well as Article 28 of the Law of Ukraine "On Protection of the Population against Infectious Diseases", it is established that sanitary and epidemiological supervision is carried out by officials of the sanitary and epidemiological service in the customs territory of Ukraine after customs clearance of goods imported into the customs territory of Ukraine. It will be limited the functions of officials of the sanitary-epidemiological service to preventive and anti-epidemic measures by conducting medical examinations of passengers, crews, etc., including people with symptoms of infectious diseases at checkpoints across the state border of Ukraine.

In our opinion, the above changes in the framework of administrative reform will have both positive and negative consequences. For example, the transfer of implementation of sanitary and epidemiological supervision of goods imported into the customs territory of Ukraine from the border into the country has signs of introducing a customs audit, and this method of monitoring complies with international standards. However, the delegation of responsibilities for checking the level of radioactive contamination of vehicles and goods from the border inland may have a negative effect in the context of the security of the state.

Until recently, in accordance with the resolution of the Cabinet of Ministers of 05.10.11 No. 1031 "Some issues of implementation of state control of goods moved across the customs border of Ukraine", the implementation of radiological control of vehicles and goods moved with their help was carried out once when imported to customs the territory of Ukraine - at checkpoints across the state border of Ukraine (points of entry into the customs territory of Ukraine) or at customs authorities of destination (for goods that move (send by postal) in international postal and express shipments) [4]. In the presence and proper functioning at the customs posts of the complex of automated control over the movements of radioactive substances and nuclear materials, such monitoring was carried out only if the natural background radiation was exceeded. Checkpoints across the state border of Ukraine are provided with the functioning of a complex of automated control over the movement of radioactive substances and nuclear materials in accordance with the provisions of Cabinet Decree No. 364, consider radiological monitoring complete, if goods are released from such a customs point across the state border of Ukraine to move them to the destination customs.

An authorized official of the State Ecological Inspectorate in the information system has to form a message about the negative results of radiological monitoring when an excess of natural radiation background is detected using automated control systems for the movement of radioactive substances and nuclear materials. The list of checkpoints across the state border of Ukraine was approved by the Order of the Ministry of Finance of July 25, 2016 No. 657, in which the complexes are in operation for the automated control of the movement of radioactive substances and nuclear materials (now there are 47 of the 196 existing) [10, 11]. In connection with the changes introduced by Law No. 2530-VIII, it is a novelty that representatives of the environmental service should be called in only when mobile devices of border guards show excess radiation levels. If a call was made, the experts should immediately arrive and within two hours decide the fate of the product or vehicle: skip, prohibit a pass or appoint inspections / sampling / additional processing. The order of interaction of the State Border Service of Ukraine and the central executive authorities, which is the implementer of state policy for the implementation 
of state control within the protection of the environment, rational use, reproduction and protection of natural resources, in identifying the excess of the allowable level of ionizing radiation of vehicles and goods moved across the state border of Ukraine, established by the Cabinet of Ministers of Ukraine.

The introduction of a state program for the arrangement of checkpoints (primarily international and interstate) with complexes controlling the movement of radioactive substances and nuclear materials will allow automating and targeting (more targeted) radiological monitoring, eliminating the human factor, avoiding unnecessary burden on the State Border Service by imposing new responsibilities. Thus, the optimization of procedures for state control of goods moved across the customs border of Ukraine requires not only the introduction of modern approaches to the implementation of the principle and mechanisms of the "single window", but also the coordination of actions, a clear division of duties and responsibility for quality, timeliness and unification of information necessary for carrying out all types of state control, between all supervisory authorities, to avoid duplication of functions and procedures, unnecessary time expenses, wider use of risk-based methods for selective selection of control objects. Law No. 2530-VIII creates a legislative framework for the application of the "single window" principle, as well as for the functioning of the unified state information web portal "Single Window for International Trade". However, the mechanism of coordinated implementation of information technology, methodological, personnel support of the authorities involved in state control of goods transported across the customs border of Ukraine needs to be developed. All this will contribute to the optimization and simplification of the procedure of state control in the implementation of foreign economic operations; a decrease in the number of regulatory authorities at checkpoints across the state border of Ukraine and in places of customs clearance of goods and vehicles within the country; improving the export potential of Ukraine; reducing the number of permits and administrative pressure for businesses; reducing the risk of corruption due to the introduction of paperless interaction between government officials and business entities.

A lot has been done to introduce a "single window" in Ukraine by this time. The State Fiscal Service has developed and put in place a software and information complex, which has been in operation since September 2016 and should ensure the exchange of information between customs, enterprises and government regulatory authorities. However, for the implementation of innovations the State Fiscal Service in the shortest possible time it is necessary:

* preparing a list of information submitted by state authorities in the "single window" and determining the content and format of this data;

* approving a set of a unified list of information when submitting it through the single state information web portal "Single Window for International Trade";

* exchanging experience with the Ministry of Ecology and Natural Resources, the State Ecological Inspectorate, organizing training seminars on the control by officials of customs posts of pesticides and agrochemicals, waste, GMOs, aquatic biological resources, species of wild fauna and flora, which are subject to the regulation of CITES Convention.

\section{Conclusions}

The introduction of administrative and legislative reforms is due to the need to improve the conditions for conducting foreign economic activity in Ukraine, reducing the time required for export-import operations and, accordingly, improving Ukraine's investment attractiveness through legislative regulation of the interaction between income authorities and fees other 
government authorities and participants in cross-border trade using the "single window" mechanism. The introduction of a "single window" mechanism with the intensification of the process of automation of control procedures is an important step in solving the problem of organizing interaction between state institutions for the control of moved goods across the customs border of Ukraine. This concerns the implementation of information technologies not only in the customs service system, but also other control authorities using software and technology complexes, with the integration of customs databases with databases of government authorities that have functions of monitoring moved goods across the customs border of Ukraine. The functioning of a single information web portal of a set of harmonized information will allow to systematize information about the requirements of customs legislation, rules, regulations and methods for carrying out operations for the movement of goods across the customs border of Ukraine, increase awareness and reduce the time costs of subjects of foreign economic activity. The full functioning of the "single window" mechanism will ensure the implementation of a number of international legal obligations of Ukraine in the framework of the WTO. At the same time, the process of practical implementation of the "single window" mechanism, its organizational and information technology improvement, requires careful study.

\section{References:}

1. Regulation (EC) No 450/2008 of the European Parliament and of the Council of 23 April 2008 laying down the Community Customs Code (Modernised Customs Code)/ Official Journal of the Europea. Retrieved from: http://eur-lex.europa.eu/LexUriServ/LexUriServ.do?uri=O$\mathrm{J}: L: 2008: 145: 0001: 0064: \mathrm{EN}: \mathrm{PDF}$

2. Finbalance-Internet portal on finance and economics, "VR pryynyala zakon pro "yedyne vikno" na mytnytsi" ["VR passed a law on the "single window" at the customs"], official site. Retrieved from: http://finbalance.com.ua/news/VR-priynyala-zakon-pro-dine-vikno-na-mitnitsi

3. KMU (2016), Deyaki pytannya realizatsiyi pryntsypu "yedynoho vikna" pid chas zdiysnennya mytnoho, sanitarno-epidemiolohichnoho, veterynarno-sanitarnoho, fitosanitarnoho, ekolohichnoho, radiolohichnoho ta inshykh vydiv derzhavnoho kontrolyu [Some issues concerning the implementation of the "one window" principle during the implementation of customs, sanitary-epidemiological, veterinary and sanitary, phytosanitary, ecological, radiological and other types of state control], the resolution of the Cabinet of Ministers of Ukraine dated May 252016 No. 364. Retrieved from: http://zakon3.rada.gov.ua /laws/show/364-2016-\%D0\%BF/ed20160525 (related to 01.10 .2018 ) [Ukraine]

4. KMU (2011), Deyaki pytannya zdiysnennya derzhavnoho kontrolyu tovariv, shcho peremishchuyut'sya cherez mytnyy kordon Ukrayiny [Some issues of the state control over goods transiting through the customs border of Ukraine], the resolution of the Cabinet of Ministers of Ukraine dated October 102011 №1031. Retrieved from: https://www.kmu.gov.ua/ua/npas/244604436 (related to 04.10. 2018)

5. Lohistyka v Ukrayini: novyny kompaniy, analityka, doslidzhennya, PR, Yedyne vikno" vstanovyly na provitryuvannya: zakonoproekt pryynyato u pershomu chytanni ["Single window" installed on ventilation: the bill was adopted in the first reading"], official site. Retrieved from: https://logistics-ukraine.com/2018/04/10 ...

6. General Directorate of the State Procurement Service in Ivano-Frankivsk region (2018), Yedyne vikno - obov"yazkove dlya vsikh z 1 lyutoho 2018 roku [Single window - mandatory for all from February 1, 2018], official site. Retrieved from: http://https://vetif.gov.ua/698-yedyne-viknoobov"yazkove-dlya-vsikh-z-1-lyutoho-2018-roku.html

7. VRU, Law of Ukraine (2012), Mytnyy kodeks Ukrayiny, [Law of Ukraine "The Customs Code of Ukraine"], dated March 13, 2012 No. 4495-VI. Retrieved from:http://zakon.rada.gov.ua/laws/ show/4495-17/ed20180704 (related to 01.10.2018) [Ukraine] 
8. International law (1982), International Convention on the Harmonization of Frontier Controls of 21.11.1982 [ International law,"Mizhnarodna konventsiya pro uz hodzhennya umov provedennya kontrolyu vantazhiv na kordonakh"], dated November 21, 1982. Retrieved from: http://zakon1.rada. gov.ua/cgibin/laws/main.cgi?nreg=995_267 (related to 01.10.2018)

9. MFU (2016), Pro zatverdzhennya perelikiv danykh, neobkhidnykh dlya funktsionuvannya informatsiyno-telekomunikatsiynoyi systemy orhaniv dokhodiv i zboriv.["On Approval of Lists of Data Required for the Functioning of the Information and Telecommunication System of Income and Duties"], the order of the Ministry of Finance of Ukraine dated July 252016 No. 657.Retrieved from:http://sfs.gov.ua/zakonodavstvo/mitne-zakonodavstvo/nakazi/69188.html

10. State Fiscal Service of Ukraine (2018), Oleksandr Vlasov: Novyy mekhanizm "yedynoho vikna» sprostyt' mytni protsedury dlya biznesu ["Alexander Vlasov: New mechanism of "single window" simplify customs procedures for business»], official site. Retrieved from: http://sfs.gov.ua/ media-tsentr/novini/354076.html

11. State Border Guard Service of Ukraine (2018), Perelik punktiv propusku, ["List of checkpoints"], official site. Retrieved from: https://dpsu.gov.ua/ru/Perelik-punktiv-propusku

12. VRU, Law of Ukraine (2018), Pro vnesennya zmin do Mytnoho kodeksu Ukrayiny ta deyakykh inshykh zakoniv Ukrayiny shchodo zaprovadzhennya mekhanizmu "yedynoho vikna" ta optymizatsiyi zdiysnennya kontrol'nykh protsedur pry peremishchenni tovariv cherez mytnyy kordon Ukrayiny [Law of Ukraine " On Amendments to the Customs Code of Ukraine and some other laws of Ukraine regarding introduction of the "one-stop shop" mechanism and optimization of control procedures during the movement of goods across the customs border of Ukraine"], dated September 092018 №2530-VIII. Retrieved from: http://zakon.rada.gov.ua/laws/show/2530-19 (related to 04.10.2018)

13. VRU, the draft Law of Ukraine (2018), Pro vnesennya zmin do Mytnoho kodeksu Ukrayiny ta deyakykh inshykh zakoniv Ukrayiny shchodo zabezpechennya funktsionuvannya mekhanizmu "yedynoho vikna" ta sproshchennya kontrol'nykh protsedur pry peremishchenni tovariv cherez mytnyy kordon Ukrayiny [The draft Law of Ukraine "On amendments to the Customs Code of Ukraine and some other laws of Ukraine on ensuring the functioning of the "one-stop shop" mechanism and simplification of control procedures when moving goods across the customs border of Ukraine”], dated August 152017 №7010-1. Retrieved from: http://w1.c1.rada.gov.ua/ pls/zweb2/ webproc4_1?pf3511=62406

14. United Nations Economic Commission for Europe (UN/ECE) (2005), Rekomendatsiya SEFAKT OON № 33 «Yedyne vikno» [UN/CEFACT Recommendation No. 33 "Single Window”], official site. Retrieved from: http://www.unece.org/cefact/ recommendations /rec index.htm

15. United Nations Economic Commission for Europe (UN/ECE) (2005), Rekomendatsiya SEFAKT OON № 34 «Yedyne vikno» [UN / CEFACT Recommendation No. 34 "Single Window"], official site.Retrieved from: http://www.unece.org/cefact/ recommendations /rec_index.htm

\title{
УДОСКОНАЛЕННЯ ВЗАЕМОДІЇ ДЕРЖАВНИХ ІНСТИТУЦІЙ \\ 3 КОНТРОЛЮ ЗА ПЕРЕМШЩЕНИМИ ТОВАРАМИ ЧЕРЕЗ МИТНИЙ КОРДОН УКРАЇНИ З ЗАСТОСУВАННЯМ МЕХАНІЗМУ «ЕДИНОГО ВІКНА»
}

\author{
ОЛЬГа БОРИСЕНКО, \\ Університет митної справи та фінансів, Україна \\ acu_borysenko@ukr.net \\ Ольга БОРКУТ, \\ Митний пост “Одеса-ичентральний” Одеської митнииі, \\ Державна фіскальна служба України, Україна \\ borkutolga@ukr.net
}


Створення та використання принципу та механізму «єдиного вікна» для міжнародної торгівлі сприяє оптимізаиії проведення процедур контролю в рамках переміщення товарних одиниць через митний кордон Украӥни та підвищення інституційної спроможності державних органів. Реалізація механізму «єдиного вікна» при митному, санітарно-епідеміологічному, ветеринарносанітарному, фітосанітарному, екологічному, радіологічному та інших видах державного контролю ускладнюється наявністю неузгодженості нормативно-правової бази з питань функиіонування «єдиного вікна» як у митній сфері, так $i$ у сфері здійснення інших видів державного контролю; недосконалістю організаційно-технічного забезпечення функиіонування «єдиного вікна»; недостатнім використанням ризик-орієнтованих методів для селективного відбору об'єктів контролю. В ході дослідження було встановлено, щчо завдяки впровадженим законодавчим змінам вдалося наблизитись до базових принцииів організації «єдиного вікна» щзодо впровадження: стандартизованості надання інформащії та подання документів, необхідних для проведення всіх видів державного контролю, через єдиний інформаційний канал; координованості дій контролюючих органів через обрання головного у системі контролюючих органів (як правило, ие митний орган) органу, який координує їх діяльність; однократності здійснення контрольних проиедур одночасно з проведенням огляду товарів.

У статті акиентовано на необхідності у найкоротиі строки провести інформаційнотехнологічне злагодження взаємодії державних інституцій з контролю за переміщеними товарами через митний кордон України щодо підготовки переліку відомостей, подання яких до «єдиного вікна» здійснюють органи державної влади, а також визначення змісту та формату иих даних; затвердження набору гармонізованих відомостей для подання їх з використанням єдиного державного інформачійного веб-порталу "ЄӘине вікно для міжнародної торгівлі»; здійснення обміну досвідом з Міністерством екології та природних ресурсів України, Державною екологічною інспекцією та організащії навчальних семінарів щодо контролю митниками специфічних зовнішньоекономічних операцій. Обтрунтовано, щзо повноцінне функиіонування механізму «єдиного вікна» сприятиме виконанню ряду міжнародно-правових зобов'язань України у рамках Світової організації торгівлі, покращить умови ведення зовнішньоекономічної діяльності в Україні.

Ключові слова: державна служба, державні інституції, контролюючі органи, митний контроль, митні процедури, взаємодія державних інститутів, механізм «єдине вікно», реформування державних інституцій. 